\title{
The Bulgarian Educational System and Gender Segregation in the Labour
}

\author{
Market \\ Revised Manuscript Draft - European Societies
}

Bieri, Franziska ${ }^{1}$, Imdorf, Christian ${ }^{2}$, Rumiana Stoilova $^{3} \&$ Boyadjieva, Pepka ${ }^{4}$

\footnotetext{
${ }^{1}$ University of Basel; Social Research and Methodology Group, Petersgraben 9/11, 4051 Basel, Switzerland (franziska.bieri@unibas.ch). Phone + 416126728 15; Fax + 41612672820

${ }^{2}$ University of Basel; Social Research and Methodology Group, Petersgraben 9/11, 4051 Basel, Switzerland (christian.imdorf@unibas.ch). Phone + 416126728 82; Fax + 41612672820

${ }^{3}$ Bulgarian Academy of Sciences; Institute for the Study of Societies and Knowledge; Moskovska 13A, 1000 Sofia, Bulgaria (RStoilova@sociology.bas.bg). Phone + 359298074 76; Fax + 35929805895

${ }^{4}$ Bulgarian Academy of Sciences; Institute for the Study of Societies and Knowledge; Moskovska 13A, 1000 Sofia, Bulgaria (pepka@sociology.bas.bg). Phone + 359298095 22; Fax + 35929805895
} 


\section{The Bulgarian Educational System and Gender Segregation in the Labour \\ Market}

\section{Introduction}

School-to-work transitions are embedded in the institutional structures of educational systems. There are some important institutional dimensions of a country's school structures that are known to be relevant to the allocation of jobs. However, a significant amount of the literature investigating the links between schooling and labour market outcomes has been gender-blind (Smyth 2005). Buchmann and Charles (1995), who have investigated how gender stratification in employment is shaped by the enrollment in general and vocational secondary schools, are an exception. Concretely, empirical evidence has linked vocational education with greater horizontal gender segregation in the labour market (Estévez-Abe 2006). Vocational education and training (VET) inclines students to develop early gender-typed career orientations, which condition them towards gender-typed transitions to work. Similarly, comparative research on higher education has revealed how stratification at the tertiary level can lead to gender segregation in the labour market. According to Smyth (2005) gender tracking at upper-secondary and also at tertiary levels produces gendered labour market entries. Hence, the horizontal gender segregation of the labour market is affected by gender-typed programs in both upper-secondary and tertiary education. However, we are not aware of studies that compare secondary and higher education and contrast their potentially dissimilar effects in shaping gendered trajectories from the educational system to the labour market.

In this study, we identify institutional features through which educational structures have an impact on gender-typical, a-typical, and mixed employment. Two institutional features of the 
educational system are investigated: vocational vs. general education and lower vs. higher education levels. A key focus is placed on differential effects of these causal mechanisms for men and women. In addition, we investigate how age, as an indicator for pre- and post-1989 education in former socialist countries, has an impact on the likelihood of working in a gendertypical, a-typical, or mixed occupation. We use data from a nationally representative, Bulgarian phone survey that was conducted in 2012, in order to test our hypotheses and we investigate the relationships between gendered labour market outcomes, various dimensions of the educational system, and relevant social factors using regression analysis.

The effects of the educational system on gendered labour market outcomes have not been studied in Bulgaria, a country which offers a particularly interesting context. Gender inequality within the labour market has remained surprisingly moderate in Bulgaria, especially in terms of gender ratios in professional and technical occupations (Hausmann et al. 2010; EU 2009; World Economic Forum 2013; Eurostat 2013). These facts are underlined by the positive positioning and mobility of female students in the educational system. Still, the country's transition to capitalism signified important changes both in Bulgaria's labour market and in its educational system, which has witnessed structural reforms including the decentralisation, liberalisation, and privatisation of educational institutions (Noelke and Müller 2011). Given these recent changes in the labour market and the educational system, which still conserves a vocational educational system that was originally established in the socialist system, Bulgaria provides an illuminative context for the investigation of the educational determinants of gender-typed employment. A case study on Bulgaria offers the opportunity to study the nexus between the educational system and the labour market in a social context of rapid transformation. In addition, our paper sheds light on these processes in an understudied European country. While the literature has 
investigated how theories on school-to-work transitions hold true in Central and Eastern European cases (Kogan et al. 2011; Kogan and Unt 2005) with a growing frequency, only a few studies have done so for Bulgaria (Kostova 2008a; Popov 2007; Stoilova and Haralampiev 2009).

The paper will proceed as follows. Our next step will consist of reviewing the relevant literature that links the educational system with horizontal gender segregation in the labour market. What follows is a summary of the Bulgarian case, highlighting the country's educational system and its gender segregation in the labour market. Then we will present the data and methodology, which is followed by the presentation of our findings. Concluding remarks are offered in the final section of the paper.

\section{The Impact of Educational Offers on Gender Segregation in the Labour Market}

Following the seminal work of Maurice et al. (1982) und Allmendinger (1989), international school-to-work transition research has demonstrated the close relationship of individual youth transitions and essential dimensions of national educational systems in Europe (see e.g. Müller and Kogan 2010). The degree of stratification and forms of differentiation in distinct educational pathways belong to the main dimensions that vary across countries. In their comparative study on school-to-work transitions in ten Central and Eastern European countries $(\mathrm{CEE})^{5}$, Kogan et al. (2011) analyse how the educational systems of those countries structure different aspects of labour market integration, including the duration needed to find a first job and the quality and stability of this job. The study highlights the efficiency of vocational

\footnotetext{
${ }^{5}$ The ten CEE countries that were analysed are: Croatia, Czech Republic, East Germany, Estonia, Hungary, Poland, Russia, Slovenia, Serbia, and Ukraine.
} 
education and training in the studied countries: upper and lower vocational graduates experience a faster labour market entry compared to general secondary graduates (Kogan et al. 2011). While, previous research on Western Europe has identified and highlighted firm-based vocational training and a strong coordination between vocational education providers and employers as key for promoting smooth school-to-work transitions, the CEE case study analysis calls these institutional explanations into doubt for transition countries. Kogan et al. (2011) explain smooth school-to-work transitions with school-based vocational education and training offers. Similarly, the case studies suggest that the more CEE countries consolidate their labour markets, the more important the role of the educational systems will become in structuring the transition to work.

International comparative research shows that the organisation of education and training does not only have an impact on youth unemployment and the quality of first employment, but also affects gender inequality in the labour market. Countries that have strongly established VET programs are known for marked horizontal gender segregation in their VET systems and in their labour markets (Estevez-Abe 2006). In their Swiss study, Buchmann and Charles (1995) have argued that young school leavers are forced to make major career choices early on in the areas of the country where VET dominates upper-secondary education. The wide variety of differentiated VET programs that are available promotes gender-typical career choices precisely at a biographical stage, when gender is particularly important in shaping young people's identity. In the case of strong institutional linkages between education and employment (such as in Switzerland or Germany), those gendered career choices in early upper-secondary school translate into different jobs for women and men later on when they are adults (Trappe 2006).

Smyth (2005) finds that gendered tracking at both upper-secondary and tertiary levels 
produces gendered labour market entries. Comparative research shows that higher education is stratified via gender-typical fields of study to varying degrees, and that the gender specificity of the various fields of study has been found to be a relevant institutional determinant in gendered labour market outcomes (Smyth and Steinmetz 2008; Reimer and Steinmetz 2009). The linkage between gendered fields of study and labour market segregation is stronger in some countries than others: The 'field of study within higher education is a stronger 'sorting mechanism' in some national systems than others' (Smyth and Steinmetz 2008: 271). Furthermore, female enrollment in tertiary education has an effect on labour market placements for both men and women: Where women make up a higher proportion of the graduates, both women and men are more likely to be found in female instead of integrated jobs and less likely to be found in male instead of integrated jobs (Smyth and Steinmetz 2008).

Hence, if we want to understand the production of horizontal gender segregation by the educational system, we need to rethink institutional characteristics such as stratification, occupational specificity and institutional linkages between education and employment and connect them with insights of gender-sensitive research on schooling and occupational choice (Imdorf et al. 2014). This paper aims to understand the ways institutional features of the educational system influence gender-typed employment by taking a closer look at the case of Bulgaria.

\section{The Case of Bulgaria}

The Bulgarian economic transformation from state socialism to market capitalism had a severe impact on the working population. The transition happened slowly and resulted in greater economic and social difficulties than in most CEE countries (Kostova 2008a). The 
transformation of the Bulgarian labour market had strong repercussions for the school-to-work transition of young adults. It was smooth under socialism, when access to employment was more or less guaranteed and young people were often assigned to their first workplace (see for CEE countries in general Kogan 2008). Under capitalism however, young people's passages from education to employment have become risky and uncertain, or as Noelke and Müller (2011:2) put it: 'The end of socialism freed young people from coercive state institutions, but the subsequent economic contraction made their social and economic positions precarious'.

The underlying transformation to capitalism was accompanied by changes in the educational system, including the liberalisation of educational institutions (Noelke and Müller 2011). The Bulgarian educational system has in fact passed substantial reforms as far as its legal framework and orientation towards the private sector are concerned (Kostova 2008a). Changes and reforms gave way to more freedom and initiative for the individual, creating possibilities to allow pupils and their families to make their own educational and vocational choices (Popov 2007). The societal transformation from a totalitarian society, where both possibilities and inequalities were leveled, towards a post-communist society opened up new opportunities in education and the labour market (Noelke and Müller 2011), while at the same time increasing differences and inequalities (Stoilova and Slavova 2006).

\subsection{The Bulgarian Educational System}

The gender distribution of general vs. vocational education at the secondary level in Bulgaria is as follows: young women are still, although decreasingly so, overrepresented in general upper-secondary education (grade 9 to 12) with 56\% in 2013/14 (Bulgarian National Statistical Institute 2014: 39; own calculation). In contrast, young men make up a majority in 
VET where they represent 6 out of 10 students (Eurostat n.d. -a). ${ }^{6}$ Still, the flexible choice most graduates have at the transition to tertiary education may prevent some of the male and female students from pursuing gender-typed career paths when moving into higher education. In other words, the majority of VET graduates get to make a 'second occupational choice', which, in early adulthood, may be less geared towards gender-stereotypes than their occupational decisions during adolescence.

The post-1989 educational system has been characterised by a process that led to enhanced social inequality and stratification. A case in point is the massification of higher education which refers to the educational expansion of the tertiary levels. Enrollment figures more than doubled within one decade with 120,000 students in 1990 to 258,000 in 2000 (Kostova 2008b: 169), and reached 283,294 in 2013 (Bulgarian National Statistical Institute 2014: 67). In 2013/14, more than half (54.5\%) of all students in Bulgaria's higher education institutions were women (Bulgarian National Statistical Institute 2014: 67). There has been a predominance of women in higher education since the late 1970s in socialist Bulgaria and this educational gap between women and men persisted throughout the 1990s, during the enormous increase in the total enrollment of students (Adnanes 2000). Thus, educational structures provide a considerable advantage for women compared to men, which is reflected in the positive positioning and the higher upward mobility for girls and women in Bulgaria's educational system (Stoilova 2012).

\footnotetext{
${ }^{6}$ This mirrors the overrepresentation of men in other CEE countries, especially in lower vocational programs, which in most countries do not grant access to university (Kogan, Noelke and Gebel 2011). In Bulgaria, although legally the path to higher education remains open for pupils with lower secondary vocational education, their lower grades at the national graduation exam (Matura) restrict their access to universities.
} 
Moreover, Bulgaria has one of the lowest field-specific gender segregation with a strong representation of females in computer science programs (Charles and Bradley 2009; Eurostat n.d.-a) and the proportion of women in traditionally male technical fields is relatively high compared to other EU countries ${ }^{7}$. Even though Bulgaria features a relatively high share of women in so-called STEM (sciences, technology, engineering, and math) subjects in international comparison, the share of women still remains limited, falling well below 50 percent. What can also be observed are changes in enrollment towards a greater number of male and female students enrolled in female-typed professional fields (Boyadjieva 2012). Hence, higher education in Bulgaria seems to be geared rather towards female-typical programs, in contrast to the VET system, where young men are highly overrepresented.

\subsection{Gender Segregation in the Bulgarian Labour Market}

Bulgaria seems to achieve greater gender equality in education and employment opportunities than many other countries (Kovacheva 2008). Moreover, occupational gender segregation has remained surprisingly moderate in Bulgaria until recently, at least in contrast to countries that are well-known for high gender inequalities within the labour market (e.g. Hausmann et al. 2010; van Langen et al. 2006). The relatively high share of Bulgarian women educated in STEM professions is reflected in their employment as can be seen in Table 1.

- Table 1 Here (full page)-

For instance, while the share of women employed in Research \& Development is $35 \%$ in the EU, the share in Bulgaria is 52\% (Eurostat 2013: 40). According to The Global Gender Gap

\footnotetext{
${ }^{7}$ With a female enrollment share of $44.8 \%$ in science, mathematics and computing Bulgaria ranks significantly higher than most countries in Europe, with an EU average of 37.3\% (Eurostat n.d. -a).
} 
Report 2013, Bulgaria tops the global ranking of the gender ratio between professional and technical workers (with 63\% females vs. 37\% males, see World Economic Forum 2013). These positive statistics might be the heritage of the former state socialist regime, where occupational sex segregation did not reach the levels found in capitalist countries, and where women's labour force participation rate was among the highest in the world (Glass 2008). However, the country's female economic activity has declined in the past decade. Bulgaria's female labour force participation rate stood at 56\% in 2002 and dropped to $49 \%$ in 2012, which represents a decline from $86 \%$ to $81 \%$ when expressed as a percent of the male labour force participation rate (UNDP 2004: 228; UNDP 2014: 172). In addition, some of those figures may increasingly come under pressure due to the decreasing age of Bulgarian women at marriage and first birth (Kovacheva 2008), as well as the growing adherence of young Bulgarian parents to traditional gender roles in dividing care responsibilities (Kovacheva 2008; Stoilova and Slavova 2006). Raising children while establishing oneself in a precarious youth labour market, with the backdrop of a weakened social welfare state, may well offer challenges to the school-to-work transitions of young parents (Kovacheva 2008). ${ }^{8}$

Next, we investigate how two institutional features of the educational system - enrollment in vocational vs. general track education and the completion of higher education - condition gender-typed, a-typical, and mixed employment in Bulgaria. Based on previous literature, we expect that vocational training increases the likelihood of men to work in male-typed and of women to work in female-typed occupations. In contrast, we expect higher education to decrease

\footnotetext{
${ }^{8}$ Indeed, the latest European gender segregation figures point to changes in Bulgaria. According to a recent EU report (European Commission's Expert Group on Gender and Employment 2009), Bulgaria is one of the countries that is experiencing re-segregation.
} 
the chances of both men and women working in male and female gender-typical occupations respectively. Finally, we expect an age effect, reflecting educational careers before and after the end of the socialist regime of educational and labour market regulation in 1989: younger workers are expected to work more often in gender-typed jobs compared to the older employees.

\section{Data and Methodology}

To test these hypotheses, we use data from a nationally representative phone survey that was conducted in 2012. The 'Sociological Survey of Labour Market Aspects in Bulgaria' is based on a sample of 1006 respondents which were selected based on a random sample of the Bulgarian population aged 18 and older and stratified by region and the size of the settlement, i.e. the size of the village, town or city. ${ }^{9}$ Conducted in February 2012, respondents provided answers to about ten closed-ended labour market questions. After the exclusion of all missing values, the total number of respondents included in this analysis is 966.

\subsection{Gender Typed Employment}

We analyse the data using regression analysis (ordered probit models). For our dependent variable - Gender Typed Job - we use the following survey question: 'Was your current (or last if currently not employed) occupation mostly exercised by men or by women?'. Respondents were given the following possible answers to choose from: almost exclusively by women; mostly by women; equally by women and men; mostly by men; almost exclusively by men; or inapplicable - has never been employed. We use the responses to construct our dependent variable 'Gender Typed Job' = 1 for respondents who report working in gender-typed occupations (female

\footnotetext{
${ }^{9}$ The standard sampling size for a nationally representative survey in Bulgaria (population 7.5 million) is usually about 1,000 .
} 
respondents reporting that their occupation is almost exclusively or mostly exercised by women, male respondents reporting that their occupation is almost exclusively or mostly exercised by men); 'Gender Typed Job' $=0$ for those reporting working in occupations which are equally exercised by women and men; and 'Gender Typed Job' = -1 for female respondents who work in male-typed jobs and male respondents in female-typed jobs. We exclude cases which selected inapplicable/has never been employed.

While our survey measures the gender type of an occupation, based on individuals' perceived professional environment, the validity of those self-reported figures is largely confirmed if one compares them to macro level data, which shows similar distributions. According to data from the 2007 European Labour Force survey report, 33 percent of Bulgarian's are in female-dominated, 36 percent in predominantly male, and 31 percent in mixed occupations (European Commission's Expert Group on Gender and Employment 2009: 93). ${ }^{10}$ Similarly, according to the Bulgarian Census and Labour Market data 35 percent of the adult Bulgarian population are employed in occupations that are female-typed, 33 percent are in male occupations and 32 work in mixed occupations (own calculations following Hakim's measure of gender segregation; using pooled Bulgarian Census and Labour Market data 2006-2010; $\mathrm{N}=3,051,335)$. According to our survey's subjective measurement, 62 percent of respondents work in gender-typed occupations, 25 percent of respondents are in mixed occupations, while 13

\footnotetext{
${ }^{10}$ The share of women in the labour force in Bulgaria in 2012 was $45 \%$ according the Human Development Report (UNDP 2014). Following Hakim's (1993) measure of gender segregation, which identifies the gender type by adding or deducting 15 percentage points from the total female share of employment, we can estimate that maledominated work refers to work with 32 percent women or less (47\%-15\%) and female-dominated occupations refer to jobs with 62 percent $(47 \%+15 \%)$ or more women. Those occupations with a female share between 33 and 61 percent are categorised as mixed.
} 
percent work in gender a-typical occupations. Put differently 42 percent of respondents report working in a male-typed occupation, while 33 percent work in a female-typed occupation. Thus, our measurement may slightly overestimate male-typed employment. While we have fewer observations in the mixed category, our data closely matches macro statistics for female-typed employment.

\subsection{Independent variables}

To measure whether respondents obtained a general or vocational education, they were asked 'On a scale from 1 to 3 please indicate to what extent your education trained you for a specific profession?'. The three possible answers were as follows: (1) I completed a general education which did not train me for a specific profession; (2) I completed an education which somewhat trained me for a specific profession; (3) I completed a vocational or professional education which trained me for a specific profession ${ }^{11}$. A dummy variable was created for vocational education (VET). The variable was coded 1 if respondents selected (3) and zero for all others.

The level of education was measured with the following survey question 'What is the highest level of education you have attained?' We created a dummy variable for higher education (HigherEdu), which equals 1 if respondents obtained tertiary education; selecting either 'First

\footnotetext{
${ }^{11}$ This particular formulation allows us to measure the general versus vocational nature of schooling across educational levels (i.e. upper secondary and tertiary education). Alternative wording options that specifically distinguish between vocational versus general education tend to be applicable only at the upper secondary level but are less suitable to inquire about the nature of the education obtained at the tertiary level. Given the high share of tertiary graduates in Bulgaria, the operationalization which we chose, i.e. the distinction between primarily general or profession specific training, is therefore most appropriate.
} 
stage of tertiary education (not leading directly to an advanced research qualification)' or 'Second stage of tertiary education (leading to an advanced research qualification)'.

Respondents reported their age in years. Additional age variables were created to measure particular cohort effects. ${ }^{12}$ Here we will report findings on the following age dummy: Plus 45 which is equal to 1 for respondents aged 45 and older, and zero otherwise. This variable distinguishes between individuals whose educational careers were achieved in the socialist pre1989 educational system and younger cohorts who gained their qualification more recently.

In addition we include two control variables: social status and ethnicity. Controlling for social status is important since both educational careers and gender-typed career decisions might be confounded by the job holders' social origin. Social status was measured with the following survey question: 'Where would you place yourself on the following scale, if the top box indicated high social standing in the country and the bottom box indicated low social standing: ${ }^{13}$. Answers ranked on a scale from 1 to 5 , with 1 indicating the lowest social standing

\footnotetext{
${ }^{12}$ In addition, we made estimations with the following age variables: age measured as a continuous variable, agesquared to account for non-linear age effects, and several cohort categorisations (under 35, 35-45, plus45, plus55). Estimations with these measurements mirrored the results of the Plus45 variable presented in the selected model. We also ran estimations with more limited samples, excluding respondents above the age of 82 (a total of 10 cases) who completed their education prior to socialist reforms. The results closely resemble those using the full sample.

${ }^{13}$ The non-response rate is significantly higher for the income question compared to the social standing variable which is why we include the latter in our analysis. Moreover, the results reported in the analysis below hold true when substituting the low social standing measure with income. We also validated the subjective measure of social standing with other income variables in our data. For example, respondents reporting low social standing have a mean monthly household income of 578 Bulgarian leva (about 290 Euro) while respondents reporting higher social standing have a more than twofold mean income of 1326 Bulgarian leva (about 680 Euro).
} 
and 5 the highest social standing. Our variable LowSocialStanding equals 1 for respondents reporting 1 or 2 on the social standing scale and zero for all the other respondents. Respondents also reported their ethnicity (Bulgarian, Turkish, Bulgarian-mohammedan, Roma or other) ${ }^{14}$. The variable Bulgarian is coded as 1 for respondents that identify themselves as Bulgarian, all other categories are coded as zero. The inclusion of ethnicity is important, especially due to the relevant linkages between ethnicity, educational achievement and labour market outcomes. In particular, minorities of Roma and Turkish descent have significantly lower enrollment rates in higher education and are more likely to experience unemployment or precarious work (Stoilova and Haralampiev 2009). Any missing values in the variables described above were dropped.

Table 2 presents the descriptive statistics and table 3 provides an overview of the key variables.

- Table 2 Here (half page)-

- Table 3 Here (half page)-

\section{Results}

In table 4 we present the results from the regression analysis, an ordered probit model ${ }^{15}$,

\footnotetext{
${ }^{14}$ In the Bulgarian context ethnicity is not associated with immigration status, but refers to domestic ethnic groups in the country.

${ }^{15}$ In addition to the ordered probit results reported here we also used several other estimation techniques and conducted robustness checks. These estimations yielded very similar results and confirm the findings presented here. Concretely, we estimated a model (probit) without the a-typical jobs category, i.e. excluding those in Gender Typed $\mathrm{Job}=-1$ (women in male-typed jobs, men in female-typed jobs), only comparing those in gender-typical (1) and mixed jobs (0). Also, we ran a separate probit analysis to estimate the likelihood of entering a female-typed, male-
} 
in which the dependent variable 'Gender Typed Job' takes on the values of 1 (gender-typed occupation), 0 (gender mixed occupation), or -1 (gender a-typical occupation).

- Table 4 Here (full page)-

We will first discuss the results of our base model, displayed in column 1. We find no significant effects of VET on gender-typed employment. Regarding higher education the data points to a significant negative effect: respondents with higher education are significantly less likely to work in a gender-typed job compared to those without higher education. Women are less likely to find themselves in gender-typed jobs compared to men. Our age variable, 45 plus, is not statistically significant.

To further investigate whether the educational effects are gender-specific, we introduce interaction variables (column 2). We interact 'female' with each of the key independent variables: vocational education, higher education, and with plus 45 . Since we have included interaction terms (*Female), the non-interacted variable coefficients for VET, HigherEdu, and Plus 45 reflect the effects for men, which is the left-out category. The results of column 2 show that men with VET are significantly more likely to work in a gender-typed, i.e. a male-typed profession compared to men who completed a general education. The significance of the interaction variable $\left(V E T^{*}\right.$ Female $)$ indicates that the effect of vocational education significantly differs by gender. While VET steers men towards male-typed employment, the same cannot be

typed or mixed typed job (the results we obtained for men in these estimations are summarised further below in Figure 1). We conducted multiple robustness checks, including different measures for social status, additional control variables like urban vs. rural education, and different age variables. Similarly, we performed gender segregated analyses, which mirror the results presented here. 
observed for women. As a test of significance revealed, VET does not have a statistically significant effect on gender-typed employment for women. ${ }^{16}$

Turning our attention to the role of higher education, we find that men with higher education are less likely to report working in a gender-typed job compared to men who did not complete higher education. Here again, the significant interaction variable (HigherEdu*Female) points to differential processes for men and women. For women we cannot observe a significant effect of higher education on gender-typed employment, as a significance test revealed (chi2 $=0.97$; prob. 0.3248 ). Lastly, men over the age of 45 are significantly less likely to report working in a gender-typical - i.e. male-typed - job compared to younger men. The significant interaction term (Plus45*Female) indicates important gender differences with regard to how age shapes the likelihood of gender-typed employment. Based on a chi-square test, age does not appear to be a relevant factor for women in predicting the gender type of their employment (chi2 $=0.46$; prob. 0.4992 ).

For robustness, we add further control variables displayed in the full model in column $3 .{ }^{17}$ The results from the previous estimates hold true: while VET increases the likelihood of men entering gender-typical professions, the reverse relationship can be observed for higher education, which steers men away from male-typed work. For women, neither vocational nor higher education explains the gender type of their occupation. While, ethnicity does not have a

\footnotetext{
${ }^{16}$ The effect for women is the sum of the non-interacted coefficient plus the interacted coefficient (0.24-0.29). A test of significance showed that this observed, small, negative effect of vocational education on male-typed employment for women is not statistically significant (chi2 $=0.14$; prob. 0.7068$)$.

${ }^{17}$ For robustness, we also included additional control variables testing for urban vs. rural differences and various age differentials. The findings obtained in those estimations are in line with the ones presented here.
} 
significant effect, we observe a positive effect of low social standing: people with low social standing are more likely to work in a gender-typed job. We also observe the relevance of age for men. Men aged 45 and older are less likely to work in gender-typical jobs. This relationship does differ by gender however, although, for women, the effect is not statistically significant.

While the results presented above provide us with information about the direction of the relationships between the educational system variables and the gender type of occupations, the actual size of the effects remains unclear: by how many percent does vocational or higher education heighten or lower the likelihood of being in a male/female or gender neutral occupation? Moreover, from the above results we cannot discern whether higher education merely steers men away from male-typed jobs towards mixed jobs ( 0 ), or whether it 'pushes' them into female-typed jobs (-1). We therefore conduct further analyses to estimate the magnitude of educational effects in steering men into gender neutral, typical or a-typical career paths ${ }^{18}$. Note that we solely focus on men, since our data does not show significant results for women for the key variables in question. We present a summary of results from the estimations in figure 1, which report the predicted differences between men with and without VET and between men with and without higher education in relation to their likelihood of being in gender neutral, typical or a-typical occupations respectively.

\footnotetext{
${ }^{18}$ We estimate three (probit) regression models based on the data of all respondents with dependent dummy variables that (1) equals 1 if a respondent reported working in an occupation that is equally exercised by men and women and zero otherwise; (2) equals 1 if a respondent reported working in an occupation that is almost exclusively or mostly exercised by men and zero otherwise; (3) equals 1 if a respondent reported working in an occupation that is almost exclusively or mostly exercised by women and zero otherwise. The independent variables are the same as in the full ordered probit model (column 3 in Table 4). Detailed regression results are available upon request.
} 
- Figure 1 Here (half page)-

We find that men with VET are significantly more likely to work in a male-typed profession. Vocational education increases men's chances to work in a male-typed occupation by 13 percent compared to men who completed general education. In contrast, VET significantly reduces men's chances of being employed in mixed or female-typed jobs compared to men with general education. Concretely, compared to men with general schooling, those who have completed VET are 8 percent less likely to work in a mixed occupation and 11 percent less likely to find themselves in a gender a-typical job.

As evident in the figure 1, the effects of higher education are quite distinct. Men with higher education are less likely to work in a male-typed occupation compared to men who did not complete higher schooling. In fact, men with higher education are nearly 15 percent less likely to find themselves in a male-typed job compared to men without higher education. While we find no significant effect of higher education on entering mixed type occupations, the effect on female-typed employment is significant and strong. Concretely, men with higher education have a 15 percent higher chance of finding themselves employed in a female-typed profession compared to male respondents without higher education. Our results uncover clear and consistent patterns of how types of education affect the gender specificity of men's occupational careers in Bulgaria.

\section{Conclusions}

In this paper we asked how vocational vs. general education and lower vs. higher education levels have an impact on the gender type of occupations in the Bulgarian labour market. Our regression results point to differential processes for men and women. While the 
educational system appears to be salient in shaping men's entry or non-entry into gender-typed jobs, it does not hold the same explanatory power for women. VET keeps men away from female-typed occupations, while steering them, as assumed, towards male-typed work. On the other hand, higher education keeps men away from male-typed jobs, while steering them towards gender a-typical occupations. We interpret these findings in the context of the early biographical timing (around age 15/16), during which men choose a VET program following Buchmann and Charles (1995) who argue that gendered VET programs promote gender-typical career choices precisely at a biographical stage, when gender is particularly important in shaping young people's identity. Moreover, gender-typed VET programs tend to reinforce gender typical career choices and future employment through gender socialization (Busch-Heizmann 2014). This reinforcement process may be particularly strong for men than for women, as male typed VET programs foster the construction of hegemonic masculine identities (Connell 2005).

In contrast, men seem more willing to leave male-typical pathways and to take up non- or a-typical educational careers at a later moment (around age 19/20 or later) when they choose a higher education program. The effect of higher education in terms of steering men towards gender a-typical occupations can be understood in the context of an increasing amount of femaletyped professional fields in Bulgaria's higher education since 1989. This process promotes men's entry into typically female jobs once they have completed higher education.

While we find that vocational and higher education are relevant factors in explaining gender-typical or a-typical employment for men, the same cannot be concluded for women. Neither vocational nor higher education significantly predicts women's placement in gendertypical, a-typical or mixed professions. The missing link between vocational education and female-typed jobs for women may be due to their growing underrepresentation in the VET 
system, as well as their limited assignment to female-typed educational programs during socialism. That higher education leads men but not women into female-typed employment runs counter to the expected trend that higher education promotes female-typed employment (Smyth and Steinmetz 2008). As was shown in Table 1, Bulgarian women have a higher enrollment in STEM and other traditionally male typed higher education programmes compared to other EU countries. This in turn could explain why women with higher education are not steered toward female typed jobs in Bulgaria. Further research is needed to analyse the processes that are relevant for women's careers.

The differential impacts of the institutional variables on gender-typed employment for men and women, points to the importance of assessing these dynamics separately for men and women. Similarly, what also warrants attention is how the educational system mitigates or reinforces broader societal inequities in Bulgaria, in regard to socio-economic status, ethnicity, their intersection with gender, and important regional differences in school-to-work transitions especially in light of the diverging educational offerings across Bulgaria.

We also find that men aged 45 and above are significantly more likely to work in femaletyped professions compared to younger men. Changes in labour market structures may be relevant with respect to these age dynamics. Specifically, the rise of service sector employment and the decline of manufacturing in Bulgaria mirror a post-industrial transition towards more female-typed service work (Castells 2002). Moreover, older men might be selected less often for male-dominated occupations because of the physical requirements, which are predominant in male-typed jobs, including for instance in transport, construction, or heavy industry. On the other hand, these age-specific effects can be understood in terms of differences in schooling. Those aged 45 and older are people who have completed their education within the socialist educational 
system. Educational selections were determined less by individual choice and more based on state planning and (pseudo) egalitarian criteria. Therefore more men chose female-typed professions than compared to after the transition. Age reflects respondents' differential school experiences in socialist and post-socialist contexts and therefore further illustrates how the educational systems condition labour market placement.

To assess the extent and comprehend the mechanisms of horizontal gender segregation in the labour market, one must consider educational institutional factors in mitigating or reinforcing gender-typical career paths for both men and women. We should keep in mind that the Bulgarian educational system has two institutional features, which (albeit not intended) might facilitate lateral occupational mobility of men and women at an early stage of their career: there is no straightforward vocational linkage between upper-secondary and tertiary educational levels and only weak linkages between the educational system and the labour market. As such, these findings have important policy implications. Overall, Bulgaria appears to have lost some of its previously achieved higher gender equality compared to other Western European countries. Still, the Bulgarian case shows the role higher education could play in decreasing occupational gender segregation in the labour market. Similarly, vocational education may not necessarily have to lead to highly gendered labour market outcomes, especially for women. 


\section{References}

Adnanes, M. (2000). Youth and Gender in Post-Communist Bulgaria. Journal of Youth Studies, 4, 25-40.

Allmendinger, J. (1989). Educational systems and labour market outcomes. European Sociological Review, 5, 231-250.

Boyadjieva, P. (2012). Higher Education and Rating Systems of Higher Schools in Bulgaria: Situation, Problems, and Outlook (published in Bulgarian). Bulgarian Journal of Science and Education Policy, 6, 5-84.

Buchmann, M. and Charles, M. (1995). Organizational and Institutional Factors in the Process of Gender Stratification: Comparing Social Arrangements in Six European Countries. International Journal of Sociology, 25, 66-95.

Bulgarian National Statistical Institute (2014). Education in the Republic of Bulgaria 2014. Sofia: National Statistical Institute.

Busch-Heizmann, A. (2014). Supply-Side Explanations for Occupational Gender Segregation: Adolescents' Work Values and Gender-(A)Typical Aspirations. European Sociological Review, 31(1), 48-64.

Castells, M. (2002). Die Macht der Identität. Teil 2 der Trilogie Das Informationszeitalter. Leske\&Budrich, Opladen.

Charles, M. and Bradley, K. (2009). Indulging Our Gendered Selves? Sex Segregation by Field of Study in 44 Countries. American Journal of Sociology, 114, 924-976. 
Connell, R. (2005). Boys, Masculinities and Curricula. The Construction of Masculinity in Practice-Oriented Subjects. ZEP, 28(4), 21-27. Retrieved February 20, 2015 from http://www.pedocs.de/volltexte/2013/6132/pdf/ZEP_4_2005_Connell_Boys.pdf

Estévez-Abe, M. (2006). Gendering the Varieties of Capitalism. A Study of Occupational Segregation by Sex in Advanced Industrial Societies. World Politics, 59, 142-75.

European Commission's Expert Group on Gender and Employment. (2009). Gender segregation in the labour market: Root causes, implications and policy responses in the EU. Directorate-General for Employment, Social Affairs and Equal Opportunities. Retrieved December 19, 2012 from http://ec.europa.eu/social/BlobServlet?docId=4028\&langId=en

Eurostat. (2013). Science, technology and innovation in Europe. Eurostat Pocketbooks. 2013 edition. Retrieved February 16, 2015 from http://ec.europa.eu/eurostat/documents/3930297/5969406/KS-GN-13-001-EN.PDF

Eurostat. (n.d. -a). Education Indicators - non-finance. Retrieved February 16, 2015 from http://ec.europa.eu/eurostat/web/education-and-training/data/main-tables

Eurostat. (n.d. -b). Gender pay gap in unadjusted form. Retrieved February 28, 2015 from http://ec.europa.eu/eurostat/web/labour-market/earnings/main-tables

Glass, C.M. (2008). Gender and Work during Transition: Job Loss in Bulgaria, Hungary, Poland, and Russia. East European Politics and Societies, 22, 757-783.

Hakim, C. (1993). Segregated and integrated occupations: A new approach to analyzing social change. European Sociological Review, 9, 89-314. 
Hausmann, R.; Tyson, L.D. and Zahidi, S. (2010). The Global Gender Gap Report 2010. Geneva: World Economic Forum.

Imdorf, C., Sacchi, S., Wohlgemuth, K., Cortesi, S. and Schoch, A. (2014). How cantonal educational systems in Switzerland promote gender-typical school-to-work transitions. Swiss Journal of Sociology, 40(2), 551-572.

Kogan, I. (2008). Educational systems of Central and Eastern European countries. In: Kogan, I., Gebel, M., and Noelke, C. (Eds.), Europe enlarged. A handbook of education, labour and welfare regimes in Central and Eastern Europe. Bristol: The Policy Press, 7-34.

Kogan, I., Noelke, C. and Gebel, M. (Eds.) (2011). Making the Transition. Education and Labour Market Entry in Central and Eastern Europe. Stanford: Stanford University Press.

Kogan, I. and Unt, M. (2005). Transition from School to Work in Transition Economies. European Societies, 7(2), 219-253.

Kostova, D. (2008a). Bulgaria. In: Kogan, I., Gebel, M. and Noelke, C. (Eds.), Europe enlarged. A handbook of education, labour and welfare regimes in Central and Eastern Europe. Bristol: The Policy Press, 97-122.

Kostova, D. (2008b). The Bulgarian educational system and evaluation of the ISCED-97 implementation. In Schneider, S. (Ed.), The International Standard Classification of Education: An Evaluation of Content and Criterion Validity for 15 European Countries. Mannheim: MZES, 162-175. 
Kovacheva, S. (2008). Combining work and family life in young people's transitions to adulthood in Bulgaria. Sociological Problems, Special Issue, 174-192.

Maurice, M., Sellier, F. and Silvestre, J. (1982). Politique d'éducation et organisation industrielle en France et en Allemagne: essai d'analyse sociétale. Paris: PUF.

Müller, W. and Kogan, I. (2010). 'Chapter 9: Education.’ In: S. Immerfall and Therborn, G. (Eds.). Handbook of European Societies. Social Transformations in the 21st Century. New York: Springer

Noelke, C. and Müller, W. (2011). Social Transformation and Educational Systems in Central and Eastern Europe. In: Kogan, I., Noelke, C. and Gebel, M. (Eds., 2011). Making the Transition. Education and Labour Market Entry in Central and Eastern Europe. Stanford: Stanford University Press, 1-28.

Popov, N. (2007). Bulgaria. In: Hörner, W., Döbert H., von Kopp B. and Mitter, W. (Eds.), The Educational systems of Europe. Dordrecht: Springer, 147-165.

Reimer, D. and Steinmetz, S.M. (2009). Highly educated but in the wrong field? Educational specialization and labour market risks of men and women in Spain and Germany. European Societies 11(5), 723-746.

Smyth, E. (2005). Gender Differentiation and Early Labour Market Integration Across Europe. European Societies, 7, 451-479.

Smyth, E. and Steinmetz, S.M. (2008). Field of study and gender segregation in European labour markets. International Journal of Comparative Sociology, 49, 257-281. 
Stoilova, R. (2012). The Influence of Gender on Social Stratification in Bulgaria. International Journal of Sociology, 42, 11-33.

Stoilova, R. and Haralampiev, K. (2009). Stratification in Bulgaria. Measuring the impact of origin, age, gender, and ethnicity on educational attainment and labour market placement. Yearbook of Sofia University 101, 89-105.

Stoilova, R. and Slavova, K. (2006). Spatial mobility and gender inequality. Sociological Problems, Special Issue, 190-207.

Trappe, H. (2006). Berufliche Segregation im Kontext. Über einige Folgen geschlechtstypischer Berufsentscheidungen in Ost- und Westdeutschland. Kölner Zeitschrift für Soziologie und Sozialpsychologie, 58, 50-78.

UNDP. (2004). Human Development Report 2004: Cultural Liberty in Today's Diverse World. Retrieved February 19, 2015 from http://hdr.undp.org/sites/default/files/reports/265/hdr_2004_complete.pdf

UNDP. (2014). Human Development Report 2014: Sustaining Human Progress: Reducing Vulnerabilities and Building Resilience. Retrieved February 19, 2015 from http://hdr.undp.org/sites/default/files/hdr14-report-en-1.pdf

van Langen, A.; Bosker, R. and Dekkers, H. (2006). Exploring Cross-National Differences in Gender Gaps in Education. Educational Research and Evaluation, 12, 155-177.

World Economic Forum. (2013). The Global Gender Gap Report 2013. Retrieved February 15, 2015 from http://www3.weforum.org/docs/WEF_GenderGap Report 2013.pdf 
Table 1. Gender Stratification in Bulgaria: A Comparative Overview

\begin{tabular}{|c|c|c|}
\hline Indicator & Percent & Source \\
\hline \multicolumn{3}{|l|}{ Labour Market } \\
\hline Female economic activity & $45 \% \mathrm{BG}$ & UNDP (2014: 172) for 2012 \\
\hline Gender pay gap* & $13 \mathrm{BG} / 16 \mathrm{EU}(28)$ & Eurostat (n.d.-b) for 2013 \\
\hline $\begin{array}{l}\text { Female share of professional and } \\
\text { technical workers }\end{array}$ & $63 \% \mathrm{BG}$ & $\begin{array}{l}\text { World Economic Forum (2013: 150) } \\
\text { for } 2013\end{array}$ \\
\hline $\begin{array}{l}\text { Female share in Research \& } \\
\text { Development }\end{array}$ & $52 \% \mathrm{BG} / 35 \% \mathrm{EU}(27)$ & Eurostat (2013: 40) for 2009 \\
\hline $\begin{array}{l}\text { Female share of financial } \\
\text { professionals }\end{array}$ & $73 \% \mathrm{BG} / 58 \% \mathrm{EU}(30)$ & EU (2009: 73) for 2007 \\
\hline Female share of managers & $30 \% \mathrm{BG} / 33 \% \mathrm{EU}(27)$ & EU (2009: 75) for 2007 \\
\hline Female share of top academic staff & $18 \% \mathrm{BG} / 14 \% \mathrm{EU}(29)$ & EU (2009: 64) for 2004 \\
\hline $\begin{array}{l}\text { Female share of computing } \\
\text { professionals }\end{array}$ & $28 \% \mathrm{BG} / 18 \% \mathrm{EU}(28)$ & EU (2009: 76) for 2007 \\
\hline \multicolumn{3}{|l|}{ Education } \\
\hline $\begin{array}{l}\text { Share of women of students in higher } \\
\text { education }\end{array}$ & $55 \% \mathrm{BG}$ & $\begin{array}{l}\text { Bulgarian National Statistical } \\
\text { Institute (2014: 67) for 2013/4 }\end{array}$ \\
\hline $\begin{array}{l}\text { General upper secondary education } \\
\text { (grade 9-12) }\end{array}$ & $56 \% \mathrm{BG}$ & $\begin{array}{l}\text { Bulgarian National Statistical } \\
\text { Institute (2014: 39) for 2013/4 }\end{array}$ \\
\hline $\begin{array}{l}\text { Share of women / men in upper } \\
\text { secondary education enrolled in } \\
\text { vocational stream }\end{array}$ & $42 \% / 58 \% \mathrm{BG}$ & Eurostat (n.d.-a) for 2012 \\
\hline $\begin{array}{l}\text { Female share in tertiary enrollment in } \\
\text { sciences, mathematics and computing }\end{array}$ & $45 \% \mathrm{BG} / 37 \% \mathrm{EU}(28)$ & Eurostat (n.d.-a) for 2012 \\
\hline $\begin{array}{l}\text { Female share in tertiary enrollment in } \\
\text { engineering, manufacturing and } \\
\text { construction }\end{array}$ & $30 \% \mathrm{BG} / 25 \% \mathrm{EU}(28)$ & Eurostat (n.d.-a) for 2012 \\
\hline
\end{tabular}

* The gender pay gap reflects the relative difference between male and female average hourly earnings. 
Table 2. Descriptive Statistics ( $\mathrm{N}=966)$

$$
\text { Variable }
$$

\section{Dependent variables}

Gender typical occupation - GenderJob

$1=$ occupation almost exclusively or mostly exercised by people

that are of the same sex as the respondent; i.e. female

respondents in female typed jobs, male respondents in male

typed jobs

$0=$ occupation exercised equally by women and men; i.e. female

and male respondents in mixed typed jobs

$-1=$ occupation almost exclusively or mostly exercised by people

that are of the opposite sex as the respondent; i.e. women in

male typed jobs, men in female typed jobs

Independent variables

Vocational Education - VET ( $1=$ vocational education $)$

Higher Education- HigherEdu (1=tertiary education)

Age

Aged 45 and over - Plus 45 (1=age $>44)$

Gender - Female $(1=$ female $)$

\section{Control variables}

Social Standing - LowSocialStanding (1= lowest 2 levels of social standing on a scale of 5)

Ethnicity - Bulgarian (1=Bulgarian)

Interactions

VET*Female

HigherEdu*Female

Plus $45^{*}$ Female
Mean (s.d.)

Min.

Max.

$0.49(0.71)$

$-1$

1

\begin{tabular}{ccc}
$0.60(0.49)$ & 0 & 1 \\
$0.34(0.47)$ & 0 & 1 \\
$50.00(15.90)$ & 18 & 92 \\
$0.61(0.49)$ & 0 & 1 \\
$0.53(0.50)$ & 0 & 1 \\
& & \\
$0.39(0.49)$ & 0 & 1 \\
$0.94(0.25)$ & 0 & 1 \\
$0.30(0.46)$ & 0 & 1 \\
$0.20(0.40)$ & 0 & 1 \\
$0.34(0.47)$ & 0 & 1 \\
\hline
\end{tabular}


Table 3. Percent in Gender Typical Occupations

\begin{tabular}{lccc}
\hline & $\begin{array}{c}\text { Percent in } \\
\text { gender a-typical } \\
\text { occupation }\end{array}$ & $\begin{array}{c}\text { Percent in } \\
\text { mixed occupation }\end{array}$ & $\begin{array}{c}\text { Percent in } \\
\text { gender-typical } \\
\text { occupation }\end{array}$ \\
\hline All & $\mathbf{1 3 \%}$ & $\mathbf{2 5 \%}$ & $\mathbf{6 2 \%}$ \\
\hline Female & $16 \%$ & $29 \%$ & $55 \%$ \\
Male & $9 \%$ & $20 \%$ & $71 \%$ \\
Higher Education & $15 \%$ & $27 \%$ & $58 \%$ \\
Vocational Education & $12 \%$ & $24 \%$ & $64 \%$ \\
Plus 45 & $15 \%$ & $23 \%$ & $62 \%$ \\
\hline
\end{tabular}


Table 4. Education and Occupational Gender Type: Regression Results

\begin{tabular}{lccc}
\hline & \multicolumn{1}{c}{$(\mathbf{1})$} & $\mathbf{( 2 )}$ & $\mathbf{( 3 )}$ \\
\hline VET & 0.10 & $0.24^{*}$ & $0.27^{* *}$ \\
& $(0.08)$ & $(0.13)$ & $(0.13)$ \\
HigherEdu & $-0.16^{*}$ & $-0.43^{* * *}$ & $-0.39^{* * *}$ \\
Plus45 & $(0.08)$ & $(0.13)$ & $(0.13)$ \\
& -0.08 & $-0.27^{* *}$ & $-0.32^{* *}$ \\
Female & $(0.81)$ & $(0.12)$ & $(0.13)$ \\
& $-0.40^{* * *}$ & $-0.63^{* * *}$ & $-0.64^{* * *}$ \\
VET*Female & $(0.08)$ & $(0.16)$ & $(0.16)$ \\
& - & $-0.29^{*}$ & $-0.32^{*}$ \\
HigherEdu*Female & - & $(0.17)$ & $(0.17)$ \\
& - & $0.51^{* * *}$ & $0.51^{* * *}$ \\
Plus45*Female & - & $(0.17)$ & $(0.17)$ \\
& & $0.37^{* *}$ & $0.39^{* *}$ \\
LowSocialStanding & - & $(0.17)$ & $(0.17)$ \\
& & - & $0.16^{*}$ \\
Bulgarian & - & - & $0.09)$ \\
& & & 0.10 \\
Wald Chi2 & 34.63 & 45.77 & $(0.17)$ \\
Pseudo R-squared & 0.0193 & 0.0269 & 49.30 \\
Number of obs. & 966 & 966 & 0.0287 \\
\hline -Stand & & & 954 \\
\hline
\end{tabular}

- Standard errors are reported in parentheses. $* \mathrm{P}<0.05, * * \mathrm{P}<0.01, * * * \mathrm{P}<0.001$.

- We report the effects from the ordered probit estimations (oprobit). In columns 1-3, we estimate an ordered probit model with a variable that equals 1 if a respondent reported working in an occupation that is almost exclusively or mostly exercised by people that are of the same sex as the respondent; equals to 0 if a respondent reported working in an occupation exercised equally by women and men; and equals -1 if a respondent reported working in an occupation almost exclusively or mostly exercised by people that are of the opposite sex. 